\title{
Viability of Brazilian distillers dried grains with solubles for pigs
}

\section{Viabilidade de grãos secos de destilaria com solúveis produzidos no Brasil para suínos}

\author{
Anderson Corassa ${ }^{1 *}$; Iziz Paula Anhon Silva Lautert²; Ana Paula Silva Ton ${ }^{1}$; Charles \\ Kiefer $^{3}$; Claudson Oliveira Brito ${ }^{4}$; Maicon Sbardella ${ }^{1}$; Henrique Campos Souza ${ }^{5}$
}

\section{Highlights}

Inclusion up to $200 \mathrm{~g} \mathrm{~kg}^{-1}$ DDGS did not affect performance and carcass of pigs.

Color parameter $\mathrm{a}^{*}$ of meat decreased linearly with increased DDGS in the diet.

Inclusion of $184.1 \mathrm{~g} \mathrm{~kg}^{-1}$ of DDGS resulted in the best economic viability.

\begin{abstract}
The purpose of this study was to evaluate the performance, carcass, meat and economic viability characteristics of pigs fed Brazilian coproducts of corn ethanol production. A total of 40 finishing pigs were subjected to four levels of distillers dried grains with solubles (DDGS; 0, 100, 200, or $300 \mathrm{~g} \mathrm{~kg}^{-1}$ ) for 28 days, and body weight, daily feed intake, daily weight gain and feed conversion were measured. After slaughter, the carcass yield, fat thickness, loin eye area, the depth and perimeter of the loin eye, and the $\mathrm{pH}$ and temperature at $45 \mathrm{~min}$ and $24 \mathrm{~h}$ post-mortem, along with the drip loss and color of the Longissimus lumborum were evaluated. The economic viability of the diets was calculated. The inclusion of DDGS showed a quadratic effect on daily feed intake over 0-14 days. Pigs fed with $300 \mathrm{~g} \mathrm{~kg}^{-1}$ of DDGS showed worse feed conversion than those fed the control diet over 0-7, 0-14 and 0-21 days. The $a^{*}$ color parameter of the meat decreased linearly with increasing DDGS concentration but the other carcass and meat characteristics were not affected. Inclusion of $184.1 \mathrm{~g} \mathrm{~kg}^{-1}$ of DDGS showed the best economic viability, considering the cost of weight gain. DDGS may be included in pig diets up to $200 \mathrm{~g} \mathrm{~kg}^{-1}$ without affecting the performance or carcass and meat characteristics, while $300 \mathrm{~g} \mathrm{~kg}^{-1}$ compromises feed conversion.
\end{abstract}

Key words: Carcass quality. DDGS. Economic analysis. Meat quality. Performance.

1 Profs., Postgraduate Program in Animal Science, Federal University of Mato Grosso, UFMT, Sinop, MT, Brazil. E-mail: anderson_corassa@ufmt.br; anatonn4@hotmail.com; msbardella@gmail.com

2 Student of Postgraduate Program in Animal Science, UFMT, Sinop, MT, Brazil. E-mail: izizpaula@zootecnista.com.br

3 Prof., Postgraduate Program in Animal Science, UFMS, Campo Grande, MS, Brazil. E-mail: charles.kiefer@ufms.br

${ }_{4}^{4}$ Prof., Federal University of Sergipe, UFS, São Cristóvão, SE, Brazil. E-mail: claudson@academico.ufs.br

${ }^{5}$ Student of Graduate in Animal Science, UFMT, Sinop, MT, Brazil. E-mail: henriquecampos.s@outlook.com

* Author for correspondence

Received: Aug. 08, 2020 - Approved: Dec. 14, 2020 


\section{Resumo}

O propósito deste estudo foi avaliar o desempenho, características de carcaça e carne e viabilidade econômica de suínos alimentados com coprodutos da produção de etanol de milho produzido no Brasil. Um total de 40 suínos em terminação foi distribuído em quatro níveis de DDGS de milho $(0,100,200$, ou $300 \mathrm{~g} \mathrm{~kg}^{-1}$ ) por 28 dias e seu peso corporal, consumo de ração diário, ganho de peso diário e conversão alimentar foram mensurados. Após o abate, rendimento de carcaça, espessura de toucinho, área de olho de lombo, profundidade e perímetro do olho de lombo, pH e temperatura a 45 min e 24 h post-mortem além da perda por gotejamento e do Longissimus lumborum foram avaliados. A viabilidade econômica das dietas foi calculada. A inclusão de DDGS mostrou efeito quadrático no consumo de ração em 0-14 dias. Suínos alimentados com $300 \mathrm{~g} \mathrm{~kg}^{-1}$ de DDGS apresentaram pior conversão alimentar em comparação àqueles da dieta controle em 0-7, 0-14 e 0-21 dias. A cor a* da carne diminuiu linearmente com aumento da concentração de DDGS nas dietas mas as outras características de carcaça e carne não foram afetadas. Inclusão de $184.1 \mathrm{~g} \mathrm{~kg}^{-1}$ de DDGS mostrou melhor viabilidade econômica, considerando o custo por ganho de peso. Os DDGS podem ser incluídos em dietas de suínos até $200 \mathrm{~g} \mathrm{~kg}^{-1}$ sem afetar o desempenho e características de carcaça e carne enquanto $300 \mathrm{~g} \mathrm{~kg}^{-1}$ compromete a conversão alimentar.

Palavras-chave: Análise econômica. DDGS. Desempenho. Qualidade de carcaça. Qualidade de carne.

\section{Introduction}

The increase in prices of corn and soybean meal in recent years has resulted greater feed costs and reduced profits for pig producers, leading to the search for new alternative products such as coproducts from the biofuel industry. The production of biofuels from corn has been limited in Brazil due to the high cost of grain; however, the situation is different in some regions with large supplies of corn and the presence of plants adapted to operate with raw material based on sugarcane and cereals and generating a significant quantity of coproduct.

Distillers dried grains with solubles (DDGS) is the coproduct obtained in production of ethanol from grains after fermentation of the starch by yeasts and enzymes and contains proteins, lipids, and high fiber concentrations, which lead to significant energy and amino acid levels and giving this material great potential to replace traditional feed ingredients in pig diets
(Wu, Johnston, Urriola, Hilbrands, Shurson 2016).

The use of DDGS in animal feed has been debated in countries where the availability of the material has been around for a long time, but there is no consensus on the impact of the ingredient in pig diets. Jacela et al. (2011) reported reduced feed intake and body weight gain with increased levels (50-300 $\mathrm{g} \mathrm{kg}^{-1}$ ) of DDGS; however, Lammers, Kerr and Honeyman (2015) found that $150 \mathrm{~g} \mathrm{~kg}^{-1}$ and 250 $\mathrm{g} \mathrm{kg}^{-1}$ DDGS had no effect on the performance of growing-finishing pigs. As a consequence, absence of knowledge of the ideal inclusion level of this ingredient is a limiting factor in its use in pig diets, especially in Brazil due to limited information on DDGS.

Thus, we hypothesize that its possible include up to $300 \mathrm{~g} \mathrm{~kg}^{-1}$ Brazilian corn DDGS in finishing pig diets without compromising performance and meat and carcass traits or affecting economic viability. 
Therefore, in this study, we aimed to evaluate the performance, carcass and meat characteristics, and economic viability of pigs fed with different concentration of Brazilian corn distillers dried grains with solubles.

\section{Material and Methods}

This study was carried out on a commercial farm at Santa Carmem, Mato

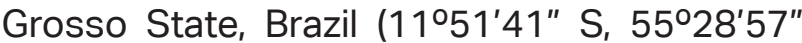
W). The study protocol was consistent with the ethical principles for animal experimentation adopted by the National Council for Animal Experimentation Control and was approved by the Ethics Committee on Animal Use of the Universidade Federal de Mato Grosso (protocol 23108.700673/14-4).

A total of 40 gilts, offspring of PIC boars mated to Camborough females (Agroceres PIC, Rio Claro, SP), were used with an initial weight of $64.14 \pm 9.31 \mathrm{~kg}$ distributed in an experimental design of randomized blocks with four treatments and five replicates, with two animals per experimental unit (pen), for 28 days. The pigs were housed in a brick shed, with asbestos cement tiles, divided into 20 pens. The pens had feeders in the front and nipple waterers in the distal part. The treatments consisted of feeding the pigs with diets containing 0 (control), 100, 200, or 300 $\mathrm{g} \mathrm{kg}^{-1}$ corn DDGS. The weight of animals was used as a criterion for forming the block.

The diets were produced based on corn and soybean meal and formulated to meet or exceed the minimum nutritional requirements suggested by Nutritional Requirements Council [NRC] (2012), (Table 1). The animals were accustomed to the experimental diets for just one day before the start of the evaluation.
The DDGS was obtained from an ethanol production plant in Mato Grosso State, using corn as the raw material. Its chemical composition (Table 2) was determined by the UFMT-Sinop Animal Nutrition Laboratory for use in the formulation of the experimental diets. The amino acid composition was determined by high-performance liquid chromatography (HPLC), and the content of each digestible amino acid was estimated from the digestibility coefficients (Adeola \& Ragland, 2016).

The performance of the pigs was evaluated weekly by the daily feed intake (DFI), daily weight gain (DWG), and feed conversion (FC), by weighing the animals and the feed leftovers using an electronic weighing-machine (150 kg, 50 g, Líder Balanças). The control of the surplus feed was conducted daily. Water and feed were provided ad libitum throughout the experimental period. The performance was evaluated over 0-7, 0-14, 0-21 and 0-28 days. 
Table 1

\section{Centesimal and calculated composition of the diets}

\begin{tabular}{|c|c|c|c|c|}
\hline \multirow{2}{*}{ Ingredient $\left(\mathrm{g} \mathrm{kg}^{-1}\right)$} & \multicolumn{4}{|c|}{ DDGS $\left(\mathrm{g} \mathrm{kg}^{-1}\right)$} \\
\hline & 0 & 100 & 200 & 300 \\
\hline Corn & 738.5 & 698.5 & 632.8 & 550.2 \\
\hline Soybean meal - $45 \%$ & 210.0 & 156.4 & 126.9 & 116.0 \\
\hline DDGS & 00.0 & 100.0 & 200.0 & 300.0 \\
\hline Soy oil & 20.0 & 12.0 & 7.0 & 1.0 \\
\hline Dicalcium phosphate & 10.0 & 10.0 & 10.0 & 10.0 \\
\hline Calcitic limestone & 5.0 & 5.0 & 5.0 & 5.0 \\
\hline Common salt & 4.0 & 4.0 & 4.0 & 4.0 \\
\hline L-Lysine & 1.3 & 3.1 & 3.7 & 3.8 \\
\hline Mineral-vitamin mix ${ }^{1}$ & 10.0 & 10.0 & 10.0 & 10.0 \\
\hline DL-Methionine & 1.2 & 1.0 & 0.6 & 0.0 \\
\hline \multicolumn{5}{|c|}{ Calculated composition per kg of mixture } \\
\hline Metabolizable energy, pigs (kcal) & 3300 & 3300 & 3300 & 3300 \\
\hline Crude protein (g) & 154.6 & 158.0 & 168.0 & 185.6 \\
\hline Calcium (g) & 5.1 & 5.0 & 4.9 & 4.7 \\
\hline Available phosphorus (g) & 2.3 & 2.5 & 2.7 & 2.9 \\
\hline Sodium (g) & 1.8 & 1.8 & 1.8 & 1.8 \\
\hline Digestible lysine (g) & 7.6 & 7.6 & 7.6 & 7.6 \\
\hline Digestible methionine $(\mathrm{g})$ & 3.0 & 3.0 & 3.1 & 3.1 \\
\hline Digestible met + cys (g) & 5.0 & 5.0 & 5.1 & 5.2 \\
\hline Digestible threonine (g) & 5.2 & 5.6 & 6.3 & 7.3 \\
\hline Digestible tryptophan (g) & 1.6 & 1.5 & 1.4 & 1.3 \\
\hline Fat (g) & 50.5 & 46.5 & 45.1 & 42.4 \\
\hline Crude fiber (g) & 23.9 & 29.4 & 35.7 & 42.7 \\
\hline NFD (g) & 117.2 & 154.9 & 193.1 & 231.8 \\
\hline
\end{tabular}

${ }^{1}$ Composition of supplement per kg of diet: vitamin A - 2,750,000 IU; vitamin B1 - 400 mg; vitamin B2 - 250 mg; vitamin B6 - 800 mg; vitamin B12 - $900 \mu$ g; vitamin D3 - 600,000 IU; vitamin E - 15,000 mg; vitamin K3 - 1250 mg; nicotinic acid - 10,000 mg; pantothenic acid - 6,000 mg; folic acid - $125 \mathrm{mg}$; cobalt - $250 \mathrm{mg}$; copper - $5000 \mathrm{mg}$; iron - 30,000 mg; zinc - 40,000 mg; manganese - 15,000 mg; selenium - 140 mg; iodine - 400 mg; choline - 50,000 mg; biotin - $5000 \mu g$; ethoxyquin - $5000 \mathrm{mg}$; BHT - 10,000 mg; bacitracin zinc - 15,000 mg 
Table 2

\section{Corn DDGS composition}

\begin{tabular}{lc}
\hline \multicolumn{1}{c}{ Nutrients } & Values $\left(\mathrm{g} \mathrm{kg}^{-1}\right)^{1}$ \\
\hline Metabolizable energy, pigs (kcal/kg) & 3590 \\
\hline Dry matter & 910.6 \\
\hline Crude protein & 286 \\
\hline Calcium & 0.4 \\
\hline Available phosphorus & 3 \\
\hline Sodium & 0.2 \\
\hline Digestible lysine & 2.8 \\
\hline Digestible methionine & 5.6 \\
\hline Digestible met + cys & 8.4 \\
\hline Digestible threonine & 13.4 \\
\hline Digestible tryptophan & 1.3 \\
\hline Digestible arginine & 6.9 \\
\hline Digestible valine & 12 \\
\hline Digestible isoleucine & 8.6 \\
\hline Digestible leucine & 33.7 \\
\hline Digestible histidine & 3.7 \\
\hline Digestible phenylalanine & 11.7 \\
\hline Digestible phenylalanine + tyrosine & 24.4 \\
\hline Fat & 64.6 \\
\hline Crude fiber & 90 \\
\hline NFD & 500 \\
\hline
\end{tabular}

${ }^{1}$ Composition based on dry matter (as-fed basis).

At the end of this stage, all animals were identified by tattooing and then subjected to fasting for $12 \mathrm{~h}$ before transportation to the abattoir in Sinop, MT (1152'23"S; 55²9'54"W; altitude $380 \mathrm{~m})$. Animals were stunned, slaughtered and eviscerated according to Brazilian Normative abattoir procedures. The carcass yield was calculated by the following formula:

Carcass yield $(\%)=$ carcass weight $(\mathrm{kg}) / \mathrm{body}$ weight (pre-slaughter, kg) × 100 .
The pHand temperature were measured in the Longissimus lumborum (LI) between $13^{\text {th }}$ and $14^{\text {th }}$ intercostal spaces, perpendicular to the midline of the left half carcass, at an average depth of $3.5 \mathrm{~cm}$ at periods of $45 \mathrm{~min}$ $\left(\mathrm{pH}_{45}\right.$ and $\left.\mathrm{T}_{45}\right)$ and $24 \mathrm{~h}$ post-mortem $\left(\mathrm{pH}_{24}\right.$ and $\mathrm{T}_{24}$ ). The $\mathrm{pH}$ was measured with portable $\mathrm{pH}$ meter AK86 interface (EC RS232 model Akso ${ }^{\circledR}$ ) with digital identification system, temperature compensation sensor, and appropriate glass electrode (SC18). The temperature was measured using a digital probe thermometer (Incoterm). In the same anatomical region, 
$24 \mathrm{~h}$ post-mortem, the back-fat thickness of the carcasses was measured using a digital caliper (150 mm, FortGPRO) by inserting one end of the caliper over the skin and the other end at the separation line of the bacon blanket with the meat, as per the Brazilian Method for Carcass Classification (Associação Brasileira de Criadores de Suínos [ABCS], 1973).

The indices loin eye area (LEA), depth of loin eye (DLA), and the perimeter of loin eye (PLE) of the $\mathrm{LI}$ were determined between $10^{\text {th }}$ and $11^{\text {th }}$ rib through the reproduction of the respective measures on tracing paper and determination of values using AutoCAD software (R14 AutoCAD version 2010, Autodesk, Inc.) as per the procedure of Santos et al. (2014).

Approximately $100 \mathrm{~g}$ of sample LI muscle was extracted from the aforementioned anatomical region for color analysis and drip loss. The color assessments were made by reading, in triplicate, the reflectance of light in three dimensions: L* (lightness), a* (range between red and green), and $b^{*}$ (variation between yellow and blue) using a colorimeter (DL65 Minolta; model CR400, CIELAB system) after a standardized period of exposure to atmospheric air for 30 min. Evaluations of drip loss were based on suspension of the samples in plastic bags inflated under the action of gravity for $48 \mathrm{~h}$ at $4{ }^{\circ} \mathrm{C}$ and weighing on a precision analytical balance $(220 \mathrm{~g}, 0.0001 \mathrm{~g}$, Pentax) (Honikel, 1998).

Based on the performance results, an analysis of the economic viability of the use of DDGS was performed using cost of weight gain (CWG) (Bellaver, Fialho, Protas and Gomes, 1985), economic efficiency index (EEI) and cost index $(\mathrm{Cl})$, adapted from Barbosa, Fialho, Ferreira, Lima and Gomes (1992). The CWG was determined by

$$
Y_{i}=\left(Q_{i} \times P_{i}\right) / G_{i}
$$

where $Y_{i}=$ cost of feed per kg of weight gained in the ith treatment; $P_{i}=$ price per $\mathrm{kg}$ of the ration used in the ith treatment; $Q_{i}=$ amount of feed consumed in the ith treatment and $G_{i}=$ weight gain of the ith treatment, and

$$
\begin{gathered}
\mathrm{IEE}=\left(\mathrm{MCe}_{\mathrm{i}} / \mathrm{CTe}_{\mathrm{i}}\right) \times 100 \text { and IC=} \\
\left(\mathrm{CTe}_{\mathrm{i}} / \mathrm{MCe}_{\mathrm{i}}\right) \times 100
\end{gathered}
$$

where $\mathrm{MCe}_{\mathrm{i}}=$ lowest cost of feed per kg gain observed among treatments and $\mathrm{CTe}_{\mathrm{i}}=$ cost of treatment considered.

The cost of each ingredient in reais (local currency, $\mathrm{R} \$ \mathrm{~kg}^{-1}$ ) used in the formulations of the diets was: DDGS, R\$ 0.28; soybean meal, $\mathrm{R} \$ 1.01$; corn, $\mathrm{R} \$ 0.25$; soybean oil, $\mathrm{R} \$ 2.28$; limestone, $\mathrm{R} \$ 0.13$; common salt, $\mathrm{R} \$$ 0.13; L-lysine HCL, R\$ 4.75; DL-methionine, $\mathrm{R} \$ 22.97$; and mineral-vitamin premix, $\mathrm{R} \$ 3.40$ ). To calculate the cost of the diets, the average dollar price ( $R$ \$ 2.6473) was used in the month of the experiment. The prices of corn and soybean meal were based on the Instituto Matogrossense de Economia Agropecuária [IMEA] (2017) prices, while the prices of the other ingredients were obtained from quotations from the local market in the month of the experiment.

Data analysis was performed by using model analysis of variance for a randomized block design, represented by:

$$
Y_{i j}=\mu+T_{i}+b_{j}+e_{i j}
$$

where $Y_{i j}=$ observed value of treatment $i(i=1,2, \ldots, t)$ in block $j(1,2, \ldots, r) ; \mu=$ constant inherent to all observations; $t_{i}=$ treatment effect $\mathrm{l}_{;} \mathrm{b}_{\mathrm{j}}=$ effect of the block and $\mathrm{e}_{\mathrm{ij}}=$ effect of experimental error associated with the observation $Y_{i j}$. 
The performance, carcass and meat qualities and economic viability were submitted to the mixed procedure of SAS (SAS Institute, Inc, Cary, NC, USA) and interpreted by analysis of variance at 0.05 probability. The estimate of the best level of inclusion of corn ethanol coproduct was determined by using linear, quadratic or cubic regression models, according to the best fit of the data for each variable and based on the phenomenon under study. The means of each treatment containing DDGS were compared with the control treatment $\left(0 \mathrm{~g} \mathrm{~kg}^{-1}\right.$ DDGS) using the Dunnett test at 0.05 probability.

\section{Results and Discussion}

The weights of pigs measured every week did not differ $(P>0.05)$ with DDGS concentration over the 28-day evaluation period (Table 3 ). The weights of pigs were found to be similar to those observed by Pompeu et al. (2013) and Graham et al. (2014a), who also found no change in the final weights of animals with up to 300 and $400 \mathrm{~g} \mathrm{~kg}^{-1}$ DDGS, respectively. However, Jacela et al. (2011) reported a linear reduction in the final body weight of pigs as a function of increasing concentration of DDGS.

Table 3

Weight (kg) of pigs fed with diets containing different concentrations of DDGS

\begin{tabular}{|ccccccccc} 
& \multicolumn{4}{c}{ DDGS $\left(\mathrm{g} \mathrm{kg}^{-1}\right)$} & \multicolumn{4}{c}{ Significance level } \\
& 0 & 100 & 200 & 300 & Linear & Quadratic & Cubic & ${ }^{1} \mathrm{CV}(\%)$ \\
\hline Day 0 & 63.14 & 64.21 & 63.96 & 64.24 & 0.5950 & 0.7536 & 0.7412 & 4.35 \\
\hline Day 7 & 67.33 & 68.46 & 68.19 & 67.21 & 0.9177 & 0.4476 & 0.9091 & 4.43 \\
\hline Day 14 & 73.08 & 74.13 & 74.19 & 71.67 & 0.5558 & 0.2693 & 0.8195 & 4.70 \\
\hline Day 21 & 78.47 & 80.02 & 79.74 & 76.00 & 0.4081 & 0.2117 & 0.8594 & 5.71 \\
\hline Day 28 & 87.97 & 88.05 & 87.55 & 84.47 & 0.3943 & 0.2753 & 0.8751 & 7.09 \\
\hline
\end{tabular}

${ }^{1} \mathrm{CV}$ : coefficient of variation.

No difference $(P>0.05)$ was noted in the DFI with different levels of DDGS during 0-7, 0-21 and 0-28 days of the experiment (Table 4). However, between 0 and 14 days, a quadratic effect $\left(Y=1.9015+0.0272 x-0.0007 x^{2} ; R^{2}=\right.$ 0.94) was noted for DDGS concentration. At $194.2 \mathrm{~g} \mathrm{~kg}^{-1}$ DDGS concentration, a higher level of DFI was estimated (2.16 kg day ${ }^{-1}$; Table 4), and from this level there was a reduction in feed intake. The rates of DWG and FC in this study showed no differences by regression analysis ( $P>0.05$ ) with the DDGS concentration in the diet, but the FC index of pigs fed with $300 \mathrm{~g} \mathrm{~kg}^{-1}$ DDGS was worse by Dunnett test $(P<0.05)$ than those fed control diet during $0-7,0-14$ and 0-21 days (Table 4). 
Table 4

Daily feed intake (DFI), daily weight gain (DWG), and feed conversion (FC) of pigs fed with diets containing different concentrations of DDGS

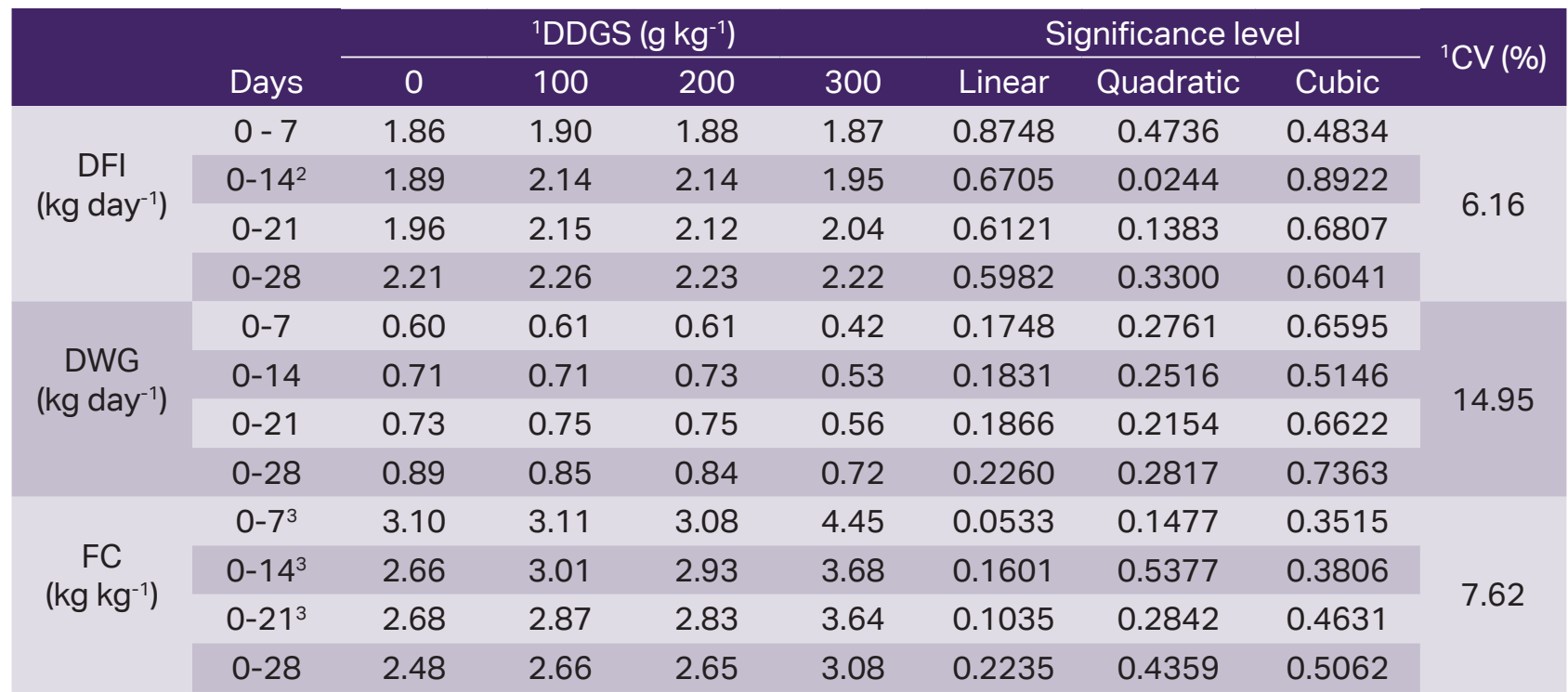

${ }^{1} \mathrm{CV}$ : coefficient of variation. ${ }^{2} \hat{Y} \mathrm{DFI}(0-14)=-1.9015+0.0272 \mathrm{x}-0.0007 \mathrm{x}^{2}, \mathrm{R}^{2}=0.94 .3$ Diet containing $300 \mathrm{~g} \mathrm{~kg}^{-1} \mathrm{DDGS}$ is different from $0 \mathrm{~g} \mathrm{~kg}^{-1} \mathrm{DDGS}$ diet by Dunnett test $(P<0.05)$.

The changing DFI in one of the initial evaluation periods may be related to the low palatability of diets containing DDGS (Jacela et al., 2011) as well as the need for the animals to adapt to diets containing greater concentrations of this ingredient, as carried out in the study. No changes in the DFI of pig was observed in other studies with up to 250 $\mathrm{g} \mathrm{kg}^{-1}$ DDGS (Lammers et al., 2015) or $300 \mathrm{~g}$ $\mathrm{kg}^{-1}$ DDGS (J. W. Lee, McKeith \& Stein, 2012; Ying et al., 2013). However, a linear reduction was noted in the DFI due to the increase in the DDGS concentration (Jacela et al., 2011).

The consumption of high-fiber diets has the potential to affect the use of nutrients and energy, resulting in a worse performance by the animals, according to a review of studies published by Agyekum and Nyachoti (2017).
However, growing-finishing pig diets containing up to $300 \mathrm{~g} \mathrm{~kg}^{-1}$ DDGS would not experience a change in their consumption of energy and nutrients so long as an adaptation period was offered so that the animals could compensate for the consumption of high-fiber and reduced energy diets. These authors suggest that the soluble fiber, which increase digesta viscosity, and insoluble fiber, which alters digesta passage rate, present in food would worsen the digestibility of dietary nutrients and may affect the performance of the pigs. Otherwise, Urriola and Stein (2010) reported that DDGS does not affect transit time in pigs, although it contains predominantly insoluble fiber.

Our results of DWG and $F C$ were in agreement with those of Pompeu et al. (2013) and Lammers et al. (2015), who evaluated 
diets containing 200 and $250 \mathrm{~g} \mathrm{~kg}^{-1}$ DDGS, respectively, and reported no difference in the performance parameters. However, Graham et al. (2014a) observed a worsening of DWG and linearly increase FC with increasing concentration of DDGS up to $450 \mathrm{~g} \mathrm{~kg}^{-1}$ in pig diets. A review of studies involving the use of DDGS for pigs by Corassa, Lautert, Silva and Souza (2018) suggested that the inclusion of up to $300 \mathrm{~g} \mathrm{~kg}^{-1}$ DDGS in the diets of growing-fattening pigs does not compromise performance.

It was observed that the animals in the treatment containing $300 \mathrm{~g} \mathrm{~kg}^{-1}$ of DDGS presented 190 and $240 \mathrm{~g} \mathrm{~kg}^{-1}$ inferior levels of DWG and FC, respectively, compared to the treatment without DDGS. This was because the diets were not isoproteic (Table 1) and generated an excess of nitrogen that may have led to the overload of organs responsible for its excretion, such as the liver and kidneys, impairing the metabolic condition of the animals fed $300 \mathrm{~g} \mathrm{~kg}^{-1}$ DDGS.
A possible negative effect on the performance of pigs fed DDGS may be related to its nutritional characteristics. High levels of fibrous components and reduced digestibility coefficients of amino acids could have harmed the performance of the animals, especially those fed diets with higher concentrations of DDGS. When evaluating the digestibility of diets containing Brazilian DDGS, Corassa et al. (2017) observed reductions in the digestibility coefficients and the digestible fractions of dry matter, organic matter and neutral detergent fiber with an increase in DDGS inclusion levels. However, the DDGS composition in this study was formulated to correct the amino acid limitations, allowing equal expression of performance by pigs fed with a corn-soybean meal diet or a $300 \mathrm{~g} \mathrm{~kg}^{-1}$ DDGS diet.

The treatments did not have any effect on the carcass weight, carcass yield, back-fat thickness, LEA or the depth and perimeter of the loin ( $P>0.05$; Table 5).

\section{Table 5}

Carcass characteristics of pigs fed with diets containing different concentrations of DDGS

\begin{tabular}{|c|c|c|c|c|c|c|c|c|}
\hline & \multicolumn{4}{|c|}{ DDGS $\left(\mathrm{g} \mathrm{kg}^{-1}\right)$} & \multicolumn{3}{|c|}{ Significance level } & \multirow{2}{*}{${ }^{1} \mathrm{CV}(\%)$} \\
\hline & 0 & 100 & 200 & 300 & Linear & Quadratic & Cubic & \\
\hline $\mathrm{HCW}(\mathrm{kg})$ & 67.74 & 67.45 & 67.07 & 64.94 & 0.4005 & 0.4903 & 0.6109 & 6.69 \\
\hline DP (\%) & 77.00 & 76.66 & 76.61 & 76.88 & 0.9631 & 0.3989 & 0.5511 & 4.32 \\
\hline BFT (mm) & 10.79 & 10.69 & 10.81 & 9.45 & 0.2480 & 0.3641 & 0.5682 & 13.8 \\
\hline LEA $\left(\mathrm{cm}^{2}\right)$ & 49.06 & 49.07 & 50.35 & 49.65 & 0.7414 & 0.8641 & 0.7392 & 9.24 \\
\hline DLA (cm) & 7.34 & 7.39 & 7.77 & 7.20 & 0.9785 & 0.2560 & 0.2303 & 6.81 \\
\hline PLE (cm) & 0.59 & 0.67 & 0.69 & 0.42 & 0.4767 & 0.3307 & 0.3734 & 4.33 \\
\hline
\end{tabular}

${ }^{1} \mathrm{CV}$ : coefficient of variation; HCW: hot carcass weight, DP - dressing percentage, BFT - back-fat thickness, LEA - loin eye area, DLA - depth of loin eye, and PLE - perimeter of loin eye. 
The ingestion of high-fiber diets suggests an increase in the secretion of enzymes and digestive juices, resulting in organ hypertrophy and adaptive changes in the gastrointestinal tract due to the increased consumption of diets with low energy content (Agyekum \& Nyachoti, 2017), which may reduce the yield of the carcass. A similar lack of an effect of the treatments on weight or carcass yield seen in the present study was also observed by Cerisuelo, Moset, Bonet, Coma and Lainez (2012), S. D. Lee et al. (2011) and McClelland, Rentfrow, Cromwell, Lindemann and Azain (2012), who reported no effects up to 350,200 , and $450 \mathrm{~g} \mathrm{~kg}^{-1}$ DDGS, respectively. However, these results contradict those presented by Graham et al. (2014 a,b), where increasing levels of DDGS caused linear decreases in the weight and carcass yield with up to 400 and $300 \mathrm{~g} \mathrm{~kg}^{-1}$ DDGS in diets, respectively. In this sense, Hilbrands et al. (2013) reported that the supply of diets with $200 \mathrm{~g} \mathrm{~kg}^{-1}$ DDGS did not result in differences in performance and carcass quality compared to corn and soybean meal diets, but when introducing diets with $400 \mathrm{~g} \mathrm{~kg}^{-1}$ DDGS, the $\mathrm{HCW}$ was reduced. The variability in response between different studies may be related to the fiber and protein content of the DDGS and the different diets.

The back-fat thickness was not different among treatments ( $P>0.05$; Table 5), which is consistent with the results of Graham et al. (2014a,b) and Wu et al. (2016), who found no differences in the back-fat thickness of pigs fed with up $300 \mathrm{~g} \mathrm{~kg}^{-1}$ DDGS. However, these responses differed from those reported by Cromwell et al. (2011), who recorded a linear decrease in the back fat of pigs fed with up 450 $\mathrm{g} \mathrm{kg}^{-1}$ DDGS.
The LEA and the depth and perimeter of loin measured in this study were not influenced by the linear increase in DDGS concentration in the diet, which is in line with the results of Graham et al. (2014a,b), who found no change in the depth of loin; and Cromwell et al. (2011), who found no change in the LEA. According to Wu et al. (2016), levels of up to $300 \mathrm{~g} \mathrm{~kg}^{-1}$ DDGS reduced fat-free lean carcass, $\mathrm{HCW}$, loin area and carcass yield but did not affect overall ADG or the FC of pigs slaughtered at $120 \mathrm{~kg}$.

The $\mathrm{pH}$ parameters and temperature in the $\mathrm{LI}$ muscle at $45 \mathrm{~min}$ and $24 \mathrm{~h}$ post-mortem did not differ ( $P$ > 0.05; Table 6); as a result, no change was observed in the drip loss $(P>0.05)$ with different concentrations of DDGS (Table 7). For colorimetric parameters, $b^{*}$ and $L^{*}$ did not differ $(P>0.05)$ while the value of $a^{*}$ of the meat decreased linearly $(Y=8.6351-0.0391 X)$ with increases in the levels of DDGS in the diets (Table 7).

The $\mathrm{pH}$ directly or indirectly influences several meat quality traits such as color, waterretaining capacity, tenderness, juiciness and flavor. After the animal is slaughtered, there is a decline in $\mathrm{pH}$, the extent and speed of which depend on the nature and condition of the muscle at the precise moment that blood stops flowing. The values of $\mathrm{pH} 45$ and $\mathrm{pH} 24$ of present study were within normal limits. S. D. Lee et al. (2011) found no differences in $\mathrm{pH}$ with a dietary DDGS concentration of 200 $\mathrm{g} \mathrm{kg}^{-1}$. Similarly, Wang, Wang, Shi, and Shan (2012) observed no change in $\mathrm{pH} 45$ and $\mathrm{pH} 24$ with up to $300 \mathrm{~g} \mathrm{~kg}^{-1}$ DDGS. 
Table 6

Temperature $(\mathrm{T})$ and $\mathrm{pH}$ of carcass of pigs fed with diets containing different concentrations of DDGS at $45 \mathrm{~min}$ and $24 \mathrm{~h}$ after slaughter

\begin{tabular}{lcccccccc}
\multirow{2}{*}{ Variable } & \multicolumn{4}{c}{ DDGS $\left(\mathrm{g} \mathrm{kg}^{-1}\right)$} \\
\cline { 2 - 7 } & 0 & 100 & 200 & 300 & Linear & Quadratic & Cubic & \multirow{2}{*}{$\mathrm{CV}(\%)$} \\
\hline $\mathrm{T}\left({ }^{\circ} \mathrm{C}\right)$ 45 min & 25.94 & 26.18 & 25.41 & 24.84 & 0.0971 & 0.2878 & 0.4717 & 3.18 \\
$\mathrm{~T}\left({ }^{\circ} \mathrm{C}\right) 24 \mathrm{~h}$ & 3.59 & 4.72 & 4.86 & 5.59 & 0.1418 & 0.7677 & 0.6055 & 31.72 \\
$\mathrm{pH} \mathrm{45} \mathrm{min}$ & 6.30 & 6.32 & 6.34 & 6.47 & 0.3902 & 0.4288 & 0.6907 & 2.28 \\
$\mathrm{pH} 24 \mathrm{~h}$ & 5.59 & 5.58 & 5.61 & 5.70 & 0.4564 & 0.4112 & 0.8802 & 2.20
\end{tabular}

${ }^{1} \mathrm{CV}$ : coefficient of variation.

Table 7

Drip loss and colors of meat of pigs fed with diets containing different DDGS concentrations

\begin{tabular}{|c|c|c|c|c|c|c|c|c|}
\hline \multirow{2}{*}{ Variable } & \multicolumn{4}{|c|}{ DDGS $\left(\mathrm{g} \mathrm{kg}^{-1}\right)$} & \multicolumn{3}{|c|}{ Significance level } & \multirow{2}{*}{${ }^{1} \mathrm{CV}$ (\%) } \\
\hline & 0 & 100 & 200 & 300 & Linear & Quadratic & Cubic & \\
\hline $\mathrm{DL}^{2}(\%)$ & 5.48 & 6.11 & 6.25 & 4.91 & 0.6901 & 0.2704 & 0.7931 & 33.52 \\
\hline$a * 3$ & 8.34 & 8.82 & 7.59 & 7.45 & 0.0213 & 0.3433 & 0.0704 & 8.71 \\
\hline$b^{*}$ & 0.81 & 1.08 & 1.17 & 0.84 & 0.8342 & 0.1502 & 0.8142 & 44.64 \\
\hline$L^{*}$ & 53.78 & 53.51 & 54.92 & 54.13 & 0.2214 & 0.5514 & 0.0723 & 1.78 \\
\hline
\end{tabular}

${ }^{1} \mathrm{CV}$ : coefficient of variation. ${ }^{2} \mathrm{DL}$ - drip loss; $3 \hat{\mathrm{Y}}=8.6351-0.0391 \mathrm{X}$. $\mathrm{a}^{*}$ - range between green and red; $b^{*}-$ range between blue and yellow; $L^{*}$ - range between bright and dull color.

The results of colorimetric parameters suggest little influence of DDGS on the color of pork, since the $L^{*}$ parameter, which is the main focus in meat classification, was not affected. S. D. Lee et al. (2011) and Wang et al. (2012) found no change in the $L^{*}, a^{*}$ and $b^{*}$ indices in pork loin with DDGS. However, results of the variable $a^{*}$ in present study showed a linear reduction ( $p=0.05$ ) with increasing levels of DDGS. Similarly, McClelland et al. (2012) found a quadratic effect on the trend in the $a^{*}$ parameter of sausage, suggesting some loss of its red color when the pigs were fed large amounts of DDGS. The greater deposition of unsaturated fatty acids in the tissues of pigs fed with DDGS (Wang et al., 2012), as well as their greater susceptibility to lipid oxidation, could be responsible for this color change.

The CWG, $\mathrm{Cl}$ and $\mathrm{EEI}$ values responded in a quadratic manner to the increase in DDGS in the diets (Table 8), presenting the best values at inclusions of $184.1 ; 183.4$ and $178.1 \mathrm{~g} \mathrm{~kg}^{-1}$, respectively (Figure 1A, B and $C$ ), which are close to the observed differences in the $200 \mathrm{~g}$ $\mathrm{kg}^{-1}$ DDGS diet compared to the control by the Dunnett test $(P<0.05)$. The results of economic viability suggest that, despite not having a significant negative impact on performance, carcass and meat characteristics, the best economic inclusion level is below the maximum inclusion investigated here. The CWG, $\mathrm{Cl}$ and EEI values were close, so the one that allows 
maximum inclusion, $184.1 \mathrm{~g} \mathrm{~kg}^{-1}$ of DDGS, is recommended.

As the inclusion of DDGS was increased, a reduction in the cost of the diets and an improvement in the economic indicators were observed. Economic viability is one of the virtues of using alternative ingredients. In this study, the inclusion of DDGS allowed a reduction in the inclusion of soybean meal and soybean oil, high-cost ingredients, besides the reduction in corn, the main ingredient, in the diets of pigs. However, with the specific inclusion of DDGS, there is a need for greater inclusions of L-lysine, which increases the costs of diets with higher levels of the alternative ingredient. It should be noted that the economic viability is directly related to the prices applied by the market and that this may vary in each situation.

\section{Table 8}

Cost of diet, (Cost), cost per unit of weight gain (CWG), economic efficiency index (EEI) and cost index (CI) of diets for pigs containing different concentrations of DDGS

\begin{tabular}{lccccccc} 
& \multicolumn{4}{c}{ DDGS $\left(\mathrm{g} \mathrm{kg}^{-1}\right)$} & \multicolumn{4}{c}{ Significance level } & \multirow{2}{*}{$\mathrm{CV}(\%)$} \\
\cline { 2 - 6 } & 0 & 100 & 200 & 300 & Linear & Quadratic & \\
\cline { 2 - 6 } Cost $\left(\mathrm{U} \$ \mathrm{~kg}^{-1}\right)$ & 0.2015 & 0.1829 & 0.1696 & 0.1583 & - & - & - \\
CWG $\left(\mathrm{U} \$ \mathrm{~kg}^{-1}\right)^{2}$ & 0.5020 & 0.4870 & 0.4505 & 0.4861 & 0.0015 & 0.0116 & 5.93 \\
$\mathrm{EEI}^{2}$ & 76.62 & 79.40 & 85.43 & 78.95 & 0.0100 & 0.0317 & 5.69 \\
$\mathrm{Cl}^{2}$ & 132.53 & 128.57 & 118.92 & 128.31 & 0.0117 & 0.0300 & 5.93
\end{tabular}

${ }^{1} \mathrm{CV}$ : coefficient of variation. ${ }^{2}$ Diet containing $200 \mathrm{~g} \mathrm{~kg}^{-1}$ DDGS is different from $0 \mathrm{~g} \mathrm{~kg}^{-1}$ DDGS diet by Dunnett test $(\mathrm{P}<$ 0.05).

A)

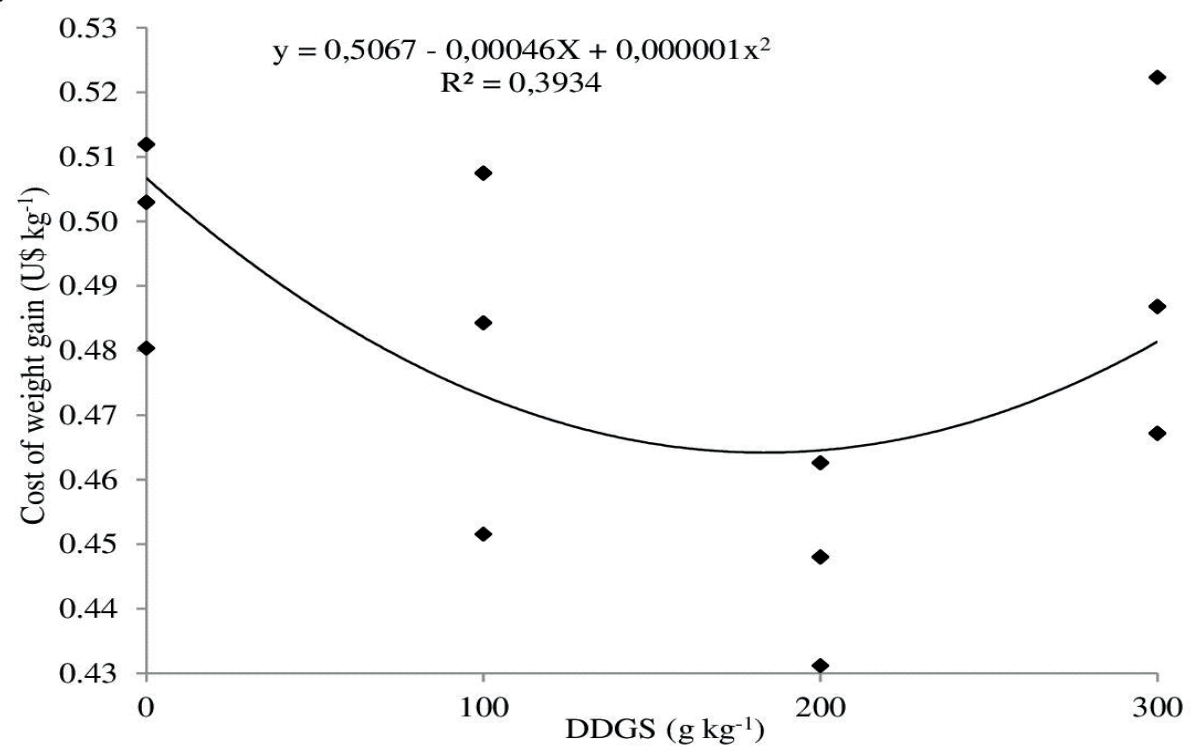


B)

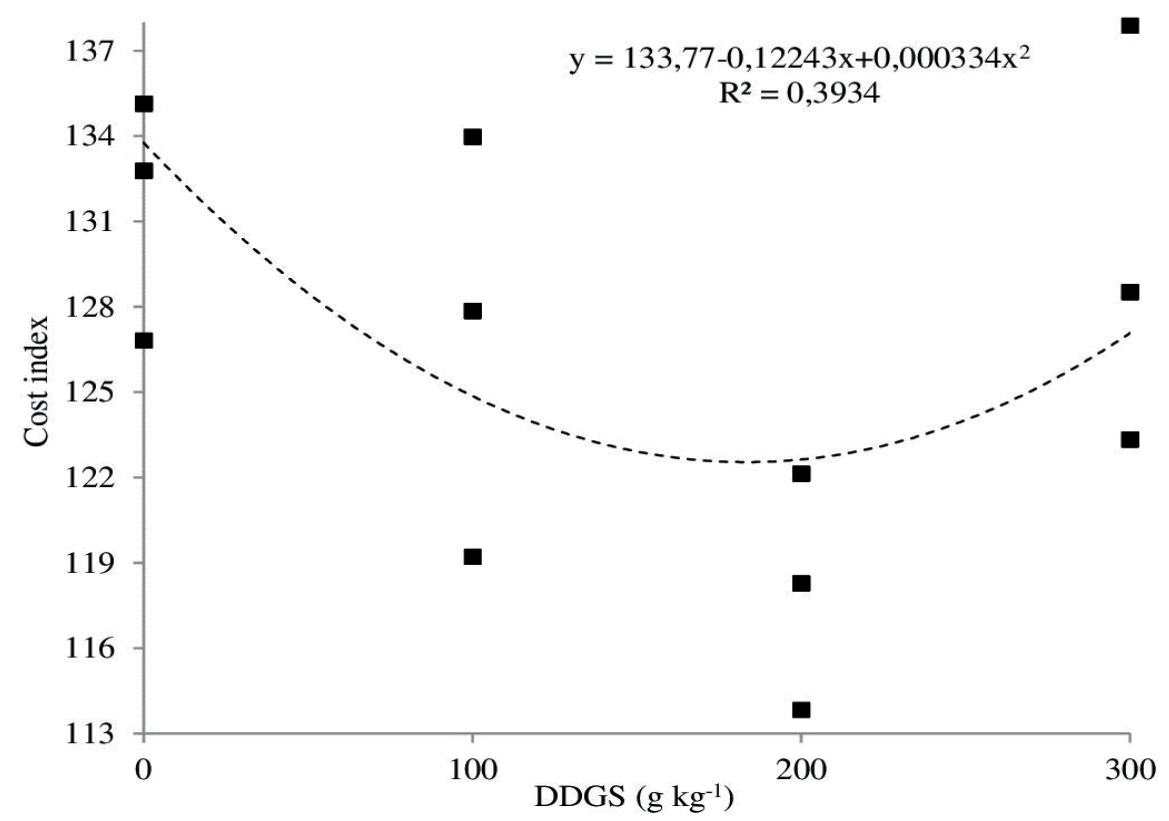

C)

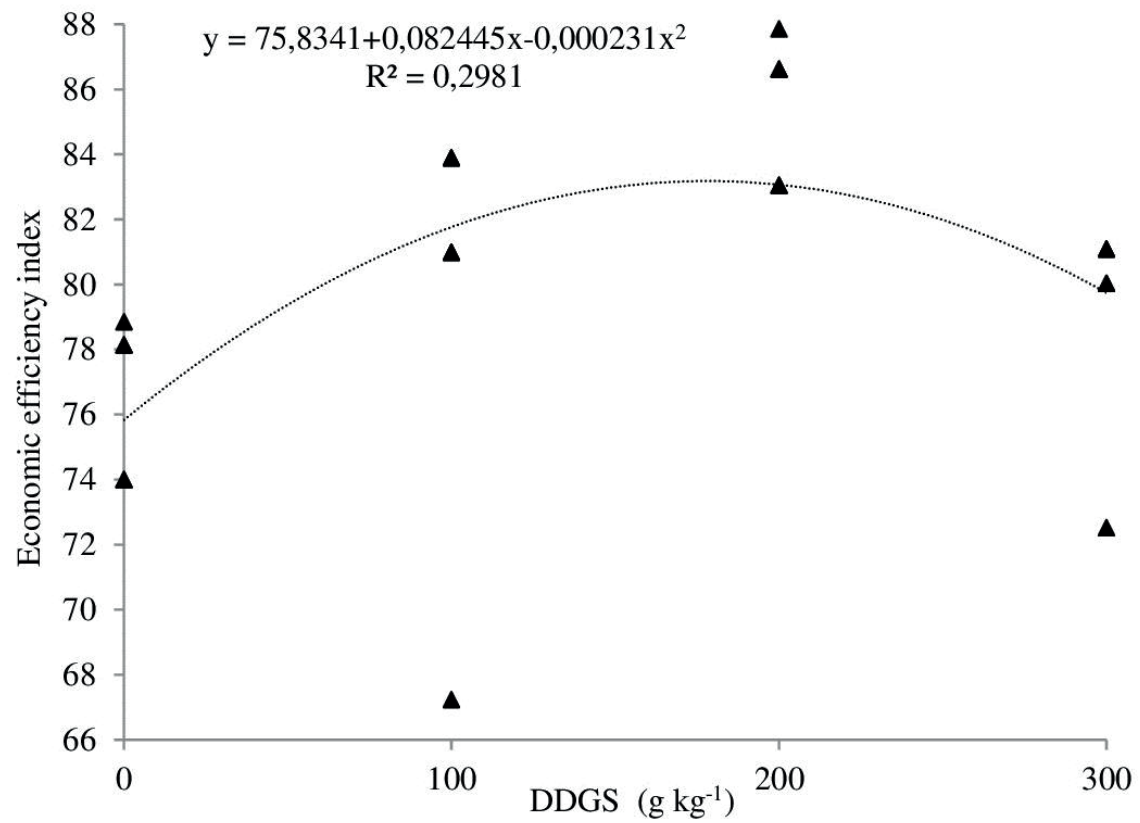

Figure 1. Cost of weight gain (A), cost index $(B)$ and economic efficiency index $(C)$ of diets for pigs containing different Brazilian DDGS concentrations. 


\section{Conclusion}

Moderate inclusion up to $200 \mathrm{~g} \mathrm{~kg}^{-1}$ Brazilian corn DDGS in the diet did not affect the performance or carcass characteristics of pigs, while inclusion at $300 \mathrm{~g} \mathrm{~kg}^{-1}$ compromised the feed conversion.

The best economic viability, based on local costs, was found with the inclusion of $184.1 \mathrm{~g} \mathrm{~kg}^{-1}$ of DDGS in diets for finishing pigs.

\section{Acknowledgments}

We acknowledge the Support Foundation of the State of Mato Grosso (FAPEMAT) for granting the scholarship to the second author and for funding this research project.

\section{References}

Adeola, O., \& Ragland, D. (2016). Comparative ileal amino acid digestibility of distillers' grains for growing pigs. Animal Nutrition, 2(4), 262-266. doi: 10.1016/j. aninu.2016.07.008

Agyekum, A. K., \& Nyachoti, C. M. (2017). Nutritional and metabolic consequences of feeding high-fiber diets to swine: a review. Engineering, 3(5), 716-725. doi: 10.1016/J.ENG.2017.03.010

Associação Brasileira de Criadores de Suínos (1973). Método brasileiro de classificação de carcaças. Estrela: ABCS.

Barbosa, H. P., Fialho, E. T., Ferreira, A. S., Lima, G. J. M. M., \& Gomes, M. F. M. (1992). Triguilho para suínos nas fases inicial de crescimento, crescimento e terminação. Revista da Sociedade Brasileira de Zootecnia, 21(5), 827-837.
Bellaver, C., Fialho, E. T., Protas, J. F. S., \& Gomes, P. C. (1985). Radícula de malte na alimentação de suínos em crescimento e terminação. Pesquisa Agropecuária Brasileira, 20(8), 969-974.

Cerisuelo, A., Moset, V., Bonet, J., Coma, J., \& Lainez, M. (2012). Effects of inclusion of sorghum distillers dried grains with solubles (DDGS) in diets for growing and finishing pigs. Spanish Journal of Agricultural Research, 10(4), 1016-1024. doi: 10.5424/sjar/2012104-520-11

Corassa, A., Lautert, I. P. A. S., Pina, D. S., Kiefer, C., Ton, A. P. S., Komiyama, C. M.,... Teixeira, A. O. (2017). Nutritional value of Brazilian distillers dried grains with solubles for pigs as determined by diferente methods. Revista Brasileira de Zootecnia, 46(9), 740746. doi: 10.1590/S1806-929020170009 00005

Corassa, A., Lautert, I. P. A. S., Silva, L. L., \& Souza, C. (2018). Uso de DDGS de milho para suínos: uma breve revisão. Scientia Agraria Paranaensis, 17(2), 157-164.

Cromwell, G. L., Azain, M. J., Adeola, O., Baidoo, S. K., Carter, S. D., Crenshaw, T. D.,... Shannon, M. C. (2011). Corn distillers dried grains with solubles in diets for growingfinishing pigs: A cooperative study. Journal of Animal Science, 89(9), 28012811. doi: 10.2527/jas.2010-3704

Graham, A. B., Goodband, R. D., Tokach, M. D., Dritz, S. S., Derouchey, J. M., \& Nitikanchana, S. (2014a). The effects of low-, medium-, and high-oil distillers dried grains with solubles on growth performance, nutrient digestibility, and fat quality in finishing pigs. Journal of Animal Science, 92(8), 3610-3623. doi: 10.2527/ jas2014-7678 
Graham, A. B., Goodband, R. D., Tokach, M. D., Dritz, S. S., Derouchey, J. M., Nitikanchana, S., \& Updike, J. J. (2014b). The effects of medium-oil distillers dried grains with solubles on growth performance, carcass traits, and nutrient digestibility in growingfinishing pigs. Journal of Animal Science, 92(2), 604-611. doi: 10.2527/jas2013-6798

Hilbrands, A. M., Johnston, L. J., McClelland, K. M., Cox, R. B., Baidoo, S. K., Souza, L. W. O., \& Shurson, G. C. (2013). Effects of abrupt introduction and removal of high and low digestibility corn distillers dried grains with solubles from the diet on growth performance and carcass characteristics of growing-finishing pigs. Journal of Animal Science, 91(1), 248-258. doi: 10. 2527/jas2012-5162

Honikel, K. O. (1998). Reference methods for the assessment of physical characteristics of meat. Meat Science, 49(4), 447-457. doi: 10.1016/S0309-1740(98)00034-5

Instituto Matogrossense de Economia Agropecuária (2017). Indicadores. Recuperado de http://www.imea. com.br/ imea-site/indicadores

Jacela, J.Y., Derouchey, J. M., Dritz, S. S., Tokach, M. D., Goodband, R. D., Nelssen, J. L.,... Prusa, K. J. (2011). Amino acid digestibility and energy content of deoiled (solventextracted) corn distillers dried grains with solubles for swine and effects on growth performance and carcass characteristics. Journal of Animal Science, 89(6), 18171829. doi: $10.2527 /$ jas.2010-3097

Lammers, P. J., Kerr, B. J., \& Honeyman, M. S. (2015). Biofuel co-products as swine feed ingredients: Combining corn distillers dried grains with solubles (DDGS) and crude glycerin. Animal Feed Science Technology, 201, 110-114. doi: 10.1016/j. anifeedsci.2014.12.013

Lee, J. W., Mckeith, F. K., \& Stein, H. H. (2012). Up to $30 \%$ corn germ may be included in diets fed to growing-finishing pigs without affecting pig growth performance, carcass composition, or pork fat quality. Journal of Animal Science, 90(13), 4933-4942. doi: 10.2527/jas2012-5129

Lee, S. D., Jung, H. J., Cho, K. H., Park, J. C., Kim, I. C., Seong, P. N., \& Song, Y. M. (2011). Effects of corn dried distiller's grains with solubles and enzyme premix supplements on growth performance, carcass characteristics and meat quality parameters in finishing pigs. Animal Science Journal, 82(3), 461-467. doi: 10.1111/j.1740-0929.2010.00848.x

McClelland, K. M., Rentfrow, G., Cromwell, G. L., Lindemann, M. D., \& Azain, M. J. (2012). Effects of corn distillers dried grains with solubles on quality traits of pork. Journal of Animal Science, 90(11), 4148-4156. doi: 10.2527/jas2011-4779

Nutritional Requirements Council (2012). Nutrient requirements of swine (11nd rev. ed.). Washington, DC: Natl. Acad. Press.

Pompeu, D., Weigand, B. R., Evans, H. L., Rickard, J. W., Gerlemann, G. D., Hinson, R. B.,... Allee, G.L. (2013). Effect of corn dried distillers grains with solubles, conjugated linoleic acid, and ractopamine (Paylean) on growth performance and fat characteristics of late finishing pigs. Journal of Animal Science, 91(2), 793-803. doi: 10.2527/jas2012-5257 
Santos, L. S., Caldara, F. R., Santos, R. K. S., Naas, I. A., Foppa, L., Garcia, R. G., \& Paz, I. C. L. A. (2014). Comparison of methodologies for assessment of pork loin eye área. Boletim da Indústria Animal, 71(3), 211-216. doi: 10.17523/bia.v71n3p211

Urriola, P. E., \& Stein, H. H. (2010). Effects of distillers dried grains with solubles on amino acid, energy, and fiber digestibility and on hindgut fermentation of dietary fiber in a corn-soybean meal diet fed to growing pigs. Journal of Animal Science, 88(4), 1454-1462. doi: 10.2527/jas.20092162

Wang, H., Wang, L., Shi, B., \& Shan, A. (2012). Effects of dietary corn dried distillers grains with solubles and vitamin $E$ on growth performance, meat quality, fatty acid profiles, and pork shelf life of finishing pigs. Livestock Science, 149(1-2), 155166. doi: 10.1016/j.livsci.2012.07.009
Wu, F., Johnston, L. J., Urriola, P. E., Hilbrands, A. M., \& Shurson, G. C. (2016). Effects of feeding diets containing distillers dried grains with solubles and wheat middlings with equal predicted dietary net energy on growth performance and carcass composition of growing-finishing pigs. Journal of Animal Science, 94(1), 144-154. doi: 10.2527/jas2015-9592

Ying, W., Tokach, M. D., Derouchey, J. M., Houser, T. E., Dritz, S. S., Goodband, R. D., \& Nelssem, J. L. (2013). Effects of dietary L-carnitine and dried distillers grains with solubles on growth, carcass characteristics, and loin and fat quality of growing-finishing pigs. Journal of Animal Science, 91(7), 3211-3219. doi: 10.2527/ jas.2012-5606 